\title{
Mutual Stimulation of Beta-Amyloid Fibrillogenesis by Clioquinol and Divalent Metals
}

\author{
Silvia Bolognin $\cdot$ Paolo Zatta $\cdot$ Denise Drago \\ Giuseppe Tognon · Pier Paolo Parnigotto • \\ Fernanda Ricchelli
}

Published online: 30 August 2008

(C) Humana Press 2008

\section{Erratum to: Neuromol Med}

\section{DOI 10.1007/s12017-008-8046-x}

The original manuscript listed the authors in an incorrect sequence. The correct order is Silvia Bolognin, Paolo Zatta,
Denise Drago, Giuseppe Tognon, Pier Paolo Parnigotto, and Fernanda Ricchelli.

The online version of the original article can be found under doi:10.1007/s12017-008-8046-x.

S. Bolognin · P. Zatta · D. Drago · G. Tognon .

F. Ricchelli $(\square)$

Department of Biology, Padova "Metalloproteins" Unit,

CNR-Institute of Biomedical Technologies,

University of Padova, Via Ugo Bassi 58B,

35121 Padova, Italy

e-mail: rchielli@mail.bio.unipd.it

P. P. Parnigotto

Department of Pharmaceutical Sciences,

University of Padova, Padova, Italy 